\title{
On the Correlation of Sea Surface Temperature and Chlorophyll in Upwelling Events from Satellite Imagery
}

\author{
Elisabeth Blazquez Gomez ${ }^{1}$, Jose J Alonso del Rosario ${ }^{1 *}$ and Juan M Vidal Perez ${ }^{2}$ \\ ${ }^{1}$ Department Applied Physics, University of Cadiz, Spain \\ ${ }^{2}$ Department Ship-building, University of Cadiz, Spain
}

Submission: July 27, 2017; Published: October 17, 2017

*Corresponding author: Jose J Alonso del Rosario, Applied Physics Department, University of Cádiz, Avda Rep Saharaui s/n, Puerto Real, 11510, Cádiz, Spain, Email: josejuan.alonso@gm.uca.es

\section{Abstract}

The relationship between SST and chlorophyll fields from satellite imagery can be computed from several methods. However, the value of the correlation of both fields uses to be lower than expected. It is demonstrated that this is due to a shift between the two fields from the time response of the biological system and the marine dynamic. Authors present a simple method to correct the shift between both fields based on the computation of their skeletons to improve the correlation.

Keywords: Upwelling; Sea Surface Temperature; chlorophyll; satellite imagery; correlation

Abbreviations: SST: Sea Surface Temperature; ITCZ: Intertropical Convergence Zone; OOD Observatorio Oceanografico Digital De Venezuela; MODIS-SCAR: Moderate Resolution Imaging Spectroradiometer Southern Caribbean

\section{Short Communication}

The oceanographic conditions of the Colombian Caribbean coast (Figure 1) are highly influenced by the quite persistent Eastern trade winds in the area [1,2]. Wind direction is mainly aligned with the coast and continental shelf inducing an Ekman's transport towards the open ocean and a coastal upwelling [2]

The upwelling uses to happen in the Peninsula de la Guajira (Figure 1). The regional oceanography is characterized by the seasonality of the upwelling events [2], determining the spatial distribution and the variability of the phytoplankton [3-8] and commercial fisheries in the area $[9,10]$.
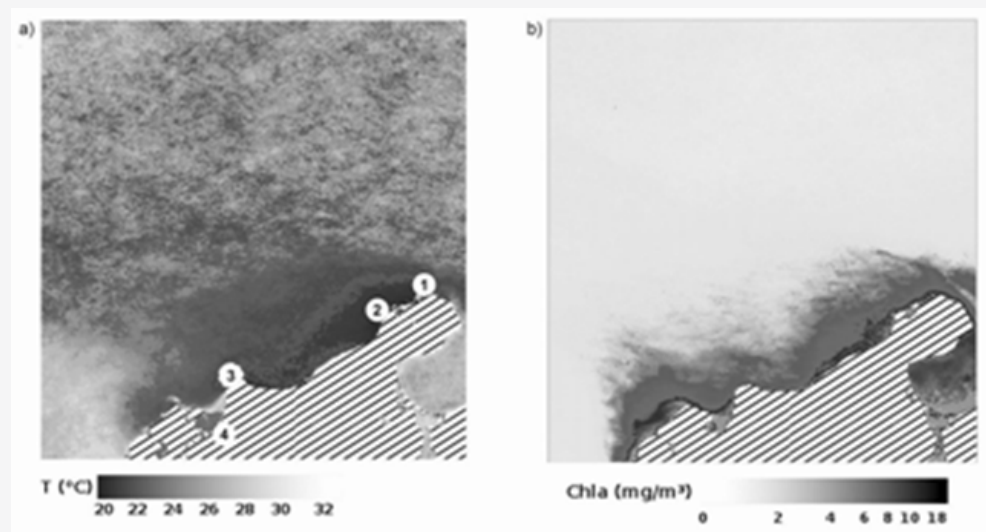

Figure 1: Area under study: Peninsula de la Guajira. (a) SST field of March 2004; (b) Chlorophyll concentration in the same month.

The upwelling events are highly spreading, so eddies with high plankton content can be found towards the open sea due to the wind drift $[11,12]$. This is relevant for the nutrient and biomass input in the oligotrophic Caribbean $[6,13]$. However, maximum plankton concentration does not always happen when the upwelling is running or trade winds are persistently 
blowing [13]. There are different ways to study the relationship between the sea surface temperature (SST) and chlorophyll from artificial satellite imagery. The correlation pixel by pixel was used in [14-16], the use of the Hovmoller diagrams can be found in [17] and in [18], finally the empirical orthogonal function analysis between time series of SST and chlorophyll was in [19]. Each technique has collateral and interesting results as it can be seen in the above references. However some difficulties can arise because the biological system, with the chlorophyll as physical observable, takes some time to react to the colder and richer in nutrients water. The use of empirical orthogonal function decomposition implies the choice by the user of several points to extract time series of SST and chlorophyll. The same happens with the use of the Hovmollers diagrams and the results will depend on transects. Finally, the direct correlation between images leads to lower correlation values than expected.

Now, the authors propose a simple approach to reduce the bias of the correlation between the images of SST and chlorophyll based in $[20,21]$. The organization of the work is as follows: the area of study and a brief of techniques of analysis are presented in Section 2. Section 3 is devoted to the results and their discussion. Finally, conclusions are drawn in Section 4

\section{Area of Study, Imagery and Computational}

Methods

\section{Area of study}

The Caribbean Sea is an oligotrophic water body with influences from the discharges of rivers Magdalena, Orinoco and Amazonas [22]. Along the Colombian Caribbean coast, the Peninsula de la Guajira is the northern point of South America. The Cabo de la Aguja is located southeast of Punta de la Guajira (Figure 1). The upwelling events take place there when the eastern trade winds blow persistently in nine detected foci along the Venezuelan and Colombian Caribbean coasts. The climate, marine weather and oceanographic phenomena in the Caribbean Sea depend on the trade winds as a consequence of the latitude of the Intertropical Convergence Zone (ITCZ) $[20,21,23,24])$.

Results

\section{Data description}

Two different MODIS-SCAR (Moderate Resolution Imaging Spectro radiometer Southern Caribbean) imagery sets have been considered. They consist of monthly composite images of SST and chlorophyll. Both have been taken from the Observatorio Oceanografico digital de Venezuela (OOD) (http://ood.cbm.usb. ve). The coordinates of the Northeast and Southwest corners are $\left(16^{\circ} \mathrm{N}, 82.7 \stackrel{\circ}{\circ}\right),\left(7.9^{\circ} \mathrm{N}, 52 .{ }^{\circ}{ }^{\circ} \mathrm{W}\right)$ for the area where the upwelling events affect the Colombian Caribbean. Imagery spans from January 2004 to March 2016 with spatial resolution of $1 \mathrm{~km}^{2}$. The monthly composite images of SST and chlorophyll for March 2004 are shown as example in Figure 1a \& 1b respectively. The surface signatures of SST and chlorophyll look quite similar and they present an inverse relationship, higher temperature lower chlorophyll [25].

\section{Digital image processing}

Following Alonso et al. [20] and Blazquez et al. [21], the SST and chlorophyll images have been processed in the same way. The downloaded imagery was converted to 8 bits gray scale images. A detailed statistical study was made to choose a threshold level for each kind of observable. This is hardly needed in order to fix the limits of what is considered o not upwelling. A mask was applied on all images to isolate the area affected by the upwelling. Such areas were then estimated by counting the unmasked pixels.

Skeleton: Skeletonization in a binary image is a process for reducing foreground regions to a one pixel width geometrical structure that largely preserves the extent and connectivity of the original region. It is also called known as Medial Axis Transform. Although it can be expressed in several ways, Lantuejoul (1977) obtained a nowadays widely used formula with basic morphological operators as it is very well detailed in Serra (1982). Because the computation of the skeleton is very sensitive to small details, authors have followed the methodology in Alonso et al. [20] \& Blazquez et al. [21], a detailed analysis of the images leaded to the computation of the skeleton of all images preserving the variance of the original grey level images.

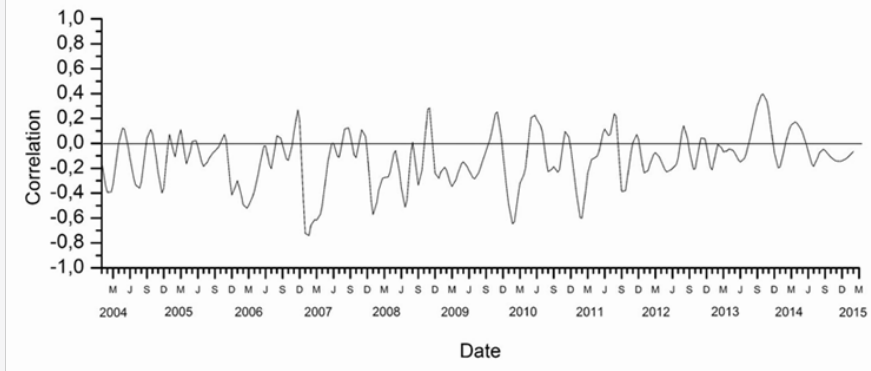

Figure 2: Direct correlation between SST and chlorophyll pair of images for all available months. 
It has been pointed out some different methodologies to study the relationship between SST and chlorophyll. The spatial correlation of each pair of images of SST and chlorophyll for all months is presented in Figure 2. Authors have been careful in not to include the pixels corresponding to the land in order to avoid additional bias. As it is observed, a negative correlation must be expected because lower temperature higher chlorophyll concentration. There are few positive values of correlation and very small. Only few times, really relevant correlations were got as at the beginning of 2007 (about -0.7) and March 2010 (about -0.6). But higher values must be expected along the time series. The correlation between the SST and chlorophyll of March 2004 (Figure 1 ) is about -0.4 but visually it may be much higher.

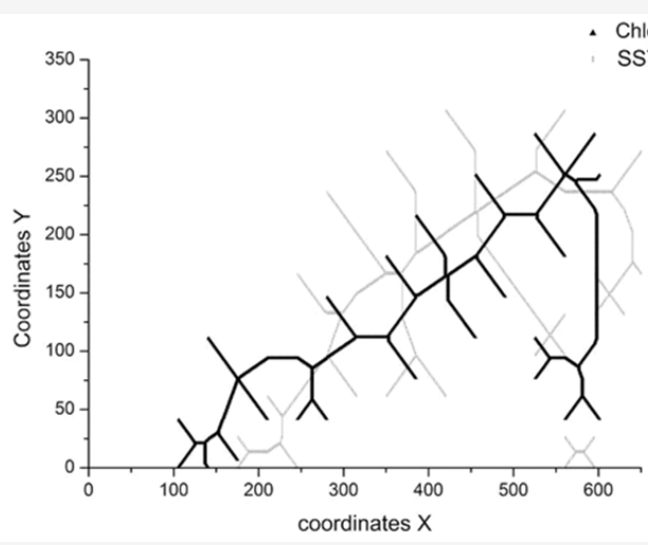

Figure 3: Skeletons of the SST and chlorophyll.

This can be easily explained by computing the skeleton of the SST and chlorophyll fields. From the joint plot of both skeletons Figure 3, it is easy to see that they look similar but they do not coincide. They are shifted but the shift is not the same in all points because the marine current field is acting, with a different drift in each point. Hence, when computing the spatial correlation a lower value than expected is obtained.

The effect of the shift on the correlation has been solved as follows. The coordinates of the skeletons were isolated from West to East and two new arrays with the values of SST and chlorophyll in such points were created. The number of points must be similar but they can be different. In this case, the cross-correlation function between both spatial series must be understood as a spatial cross-correlation. Its maximum will correspond to the correlation of both data sets when the shift is compensated. The unbiased by shift compensation correlations are presented in Figure 4. Now the correlation for March 2004 (Figure 1 ) is about -0.87 . The comparison of Figure $2 \& 4$ shows an improvement of the correlations. Those places with zero correlation means that there is no upwelling acting and no skeleton could be computed [26].

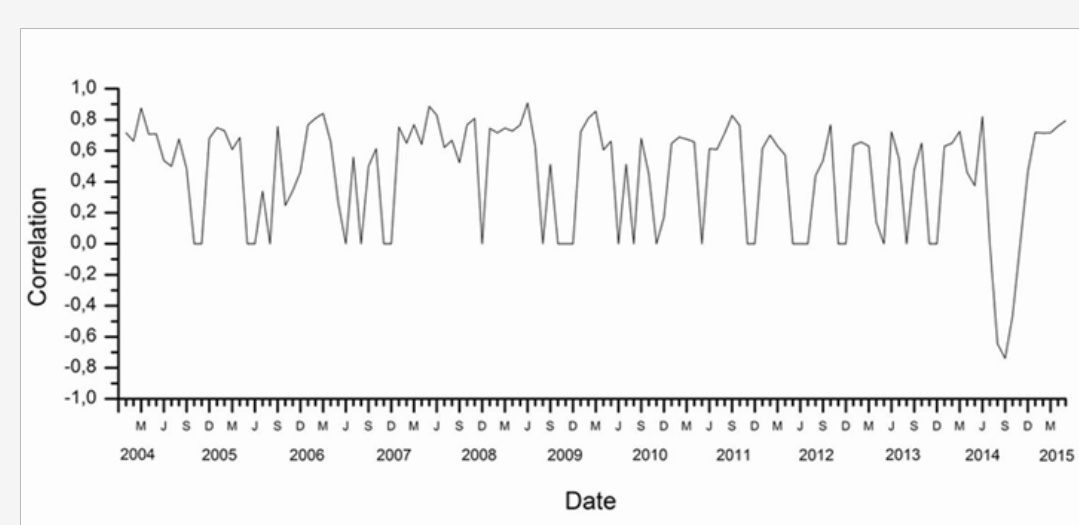

Figure 4: Correlation of SST and chlorophyll fields when shifting is compensated. All values are negative.

\section{Conclusion}

The relationship between SST and chlorophyll fields from satellite imagery can be computed from several methods. However, both fields are shifted because of the time response of the biological system to the marine dynamic and wind drift. The computation of the skeletons of both fields leads to some shift between them. Hence, the direct correlation between both images leads to lower values than expected. Authors 
have developed a simple method to correct the shift between the skeletons of both fields. The values of both observables at the locations of the skeletons form two spatial series of values and their cross-correlation helps to determine the shift and the correlation. Finally, although this method is quite general, every area of the ocean has its own characteristics and physical configuration, needing to be adapted.

\section{Acknowledgment}

This study is part of the previous work partially granted by a scholarship from the University of Cadiz to Ms. Blazquez for a short staying at Jet Propulsion Laboratory and Californian Institute of Technology.

\section{References}

1. Andrade A, Carlos A (1993) Analisis de la velocidad del viento en el mar Caribe. Boletin Cientofico Centro de Investigaciones Oceanograficas e Hidrograficas 13: 33-43.

2. Andrade CA, Barton ED, Christoper NK, Mooers (2003) Evidence for an eastward flow along the Central and South American Caribbean Coast. Journal of Geophysical Research 108(C6): 1-11.

3. Caicedo IE (1975) Productividad primariay fitoplancton en la Bahia de Neguange (Parque Nacional Natural Tayrona). Anales del Instituto de Investigaciones Marinas Punta de Betin 9: 7-14.

4. Duarte G (1996) Estructura del fitoplancton al noroeste de la Guajira, durante el crucero Caribe 1-93. Trabajo de Biologia Marina, Universidad de Bogota Jorge Tadeo Lozano, Santa Marta, Colombia, p. 98.

5. Tigreros P (2001) Biodiversidad y valoración bioquímica del fitoplancton marino en ambientes costeros mesotróficos y oligotróficos tropicales, Caribe colombiano. Tesis de Biología Marina, Universidad de Bogotá Jorge Tadeo Lozano, Bogotá, Colombia, p. 173.

6. Franco-HA, Torres-SEA (2006) La comunidad fitoplanctonica en el evento de surgencia frente al mar Caribe centro de Colombia. Actualidades y Divulgacion Cientifica 39(2): 233-263.

7. Suarez-VV, Franco-HA, Cañón ML (2007) El microfitoplancton en los principales muelles de la Bahía de Cartagena, Caribe colombiano, vectores posibles de floraciones microalgales. Boletín Científico $\mathrm{CIOH} 25$ : 135-149.

8. Arevalo-MD, Franco-HA (2008) Caracteristic as oceanograficas de la surgencia frente a la Ensenada de Gaira, Departamento del Magdalena. Boletin de Investigaciones Marinas y Costeras 37(2): 131-162.

9. Paramo J, Roa R (2003) Acoustic-geostatistical assessment and habitat-abundance relations of small pelagic fish from the Colombian Caribbean. Fisheries Research 60: 309-319.

10. Paramo J, Guillot-IL, Benavides S, Rodríguez A, Sánchez-RC (2009) Aspectos poblacionales y ecológicos de peces demersales de la zona norte del Caribe colombiano en relación con el hábitat: una herramienta para identificar áreas marinas protegidas (AMPs) para el manejo pesquero. Caldasia 31(1): 2357-3759.

11. Roy C (1998) Upwelling-induced retention area: a mechanism to link upwelling and retention processes. South African Journal of Marine Science 19(1): 89-98.
12. Mackenzie BR (2000) Turbulence, larval fish ecology and fisheries recruitment: a review of field studies. Oceanologica Acta 23(4): 357-376.

13. Garcia-HLM (2008) Dinamica en el acoplamiento oceano-atmosfera y su influencia en la biomasa fitoplanctonica durante un evento de surgencia y no surgencia en la zona costera del departamento del Magdalena. Tesis de Biologia Marina, Universidad de Bogotá Jorge Tadeo Lozano, Santa Marta, Colombia, p. 130.

14. Weeks SJ, Barlow R, Roy C, Shillington FA (2006) Remotely sensed variability of temperature and chlorophyll in the southern Benguela: upwelling frequency and phytoplankton response. African Journal of Marine Science 28(3-4): 493-509.

15. Kavak MT, Karadogan S, (2012) The relationship between sea surface temperature and chlorophyll concentration of phytoplanktons in the Black Sea using remote sensing techniques. J Environ Biol 33(2 Suppl): 493-498.

16.Zamir UB, Masood H, Jamil N, Muniza AB (2015) The Relationship between Sea Surface Temperature and Chlorophyll-a Concentration in Arabian Sea. Biological Forum - An International Journal 7(2): 825834.

17. Saraceno M, Provost C, Piola AR (2005) On the relationship between satellite-retrieved surface temperature fronts and chlorophyll a in the western South Atlantic. Journal of Geophysical Research 110(C11).

18. Herrera-CH, Lluch-CSE, Lluch-CDB, Gutiérrez-de-VG (2014) Interannual correlations between sea surface temperature and concentration of chlorophyll pigment off Punta Eugenia, Baja California, during different remote forcing conditions. Ocean Sci 10: 345-355.

19. Wilson C, Adamec D (2001) Correlations between surface chlorophyll and sea surface height in the tropical Pacific during the 1997-1999 El Niño-Southern Oscillation event, Journal of Geophysical Research 106(C12): 31175-31188.

20. Alonso J, Blazquez E, Isaza-TE, Vidal J (2015) Internal structure of the upwelling events at Punta Gallinas (Colombian Caribbean) from MODIS-SST Imagery. Continental Shelf Research 109: 127-134.

21. Blazquez E, Alonso J, Vidal J (2017) On the sensitivity of the fractal dimension of the skeleton of SST signatures from upwelling events on spatial resolution and threshold: Application on MODIS-SCAR imagery of the Caribbean Sea. International Journal Remote Sensing (submitted) 38(2): 371-390.

22. Muller-KFE, McClain CR, Fisher TR, Esaias WE, Varela R (1989) Pigment distribution in the Caribbean Sea: Observations from Space. Progress in Oceanography 23(1): 23-64.

23. Vernette G (1985) La plataforme continentale Caraibe du Colombie (du débouché du Magdalena au golfe de Morrosquillo) importante du diapirisme argileux sur la morphologie et la sedimentation. Unpublished Ph.D Thesis, University Bordeaux I, France.

24. Nystuen JA, Andrade CA (1993) Tracking mesoscale ocean features in the Caribbean Sea using geosat altimetry. Journal of Geophysical Research 98 (C5): 8389-8394.

25. Andrade C, Barton E (2005) The Guajira upwelling system. Continental Shelf Research 25: 1003-1022.

26. Paramo J, Quiñones RA, Ramírez A, Wiff R (2003) Relationship between biomass density of small pelagic and environmental factors in the Colombian Caribbean Sea: an analysis based on hydroacustic information. Aquatic Living Resources 16: 239-245. 
(C) (1) This work is licensed under Creative

cc)

DOI: 10.19080/OFOAJ.2017.05.555655

\section{Your next submission with Juniper Publishers} will reach you the below assets

- Quality Editorial service

- Swift Peer Review

- Reprints availability

- E-prints Service

- Manuscript Podcast for convenient understanding

- Global attainment for your research

- Manuscript accessibility in different formats

( Pdf, E-pub, Full Text, Audio)

- Unceasing customer service

Track the below URL for one-step submission https://juniperpublishers.com/online-submission.php 